DOI https://doi.org/10.30525/978-9934-26-148-0-33

\title{
ПРИНЦИПИ ГЕНДЕРНОЇ ПОЛІТИКИ ТА ЇХ ВПРОВАДЖЕННЯ В ДІЯЛЬНІСТЬ ПОЛІЦІї
}

\author{
Лях Н. В. \\ старший викладач кафедри поліцейського права \\ Національної академії внутрішніх справ \\ м. Київ, Україна
}

За умов постійного оновлення форм соціального життя та стрімких змін у політикоправовому становищі жінки, актуальним залишається питання гендерної рівності, вирішення якого потребує реалізації гендерної політики, що спрямована на формування нового світогляду та визначення ролі жінки в суспільстві та системі державного управління.

3 метою забезпечення гендерної рівності та формування гендерно збалансованого суспільства необхідно забезпечити паритетну демократію. "Паритетна демократія - це політико-правова форма організації соціально-статевих відносин у суспільстві, за якої жінки i чоловіки мають рівний правовий та політичний статус і як рівноправні представники здійснюють діяльність в гендерно збалансованих органах влади та управлінських структурах" [1, с. 153].

Безумовно, що під час становлення паритетної демократії важливим показником її якості є гендерна рівність - тобто рівний правовий статус жінок і чоловіків та рівні можливості для його реалізації, що дозволяє особам обох статей брати однакову участь у житті суспільства [1]. Гендерну рівність також можна визначити як: справедливе ставлення до жінок і чоловіків; ознака правової держави; показник рівня розвиненості суспільства; умова розвитку демократії.

Гендерна політика держави визначається, як діяльність держави, що проводиться шляхом реалізації спільних дій зацікавлених суб'єктів 3 метою забезпечення однакових можливостей для жінок та чоловіків у процесі реалізації гарантованих прав та свободами, забезпечення оптимальних умов для самореалізації та $\epsilon$ інтегруючим компонентом усіх напрямів державної кадрової політики. Формування гендерної політики в Україні потребує комплексного підходу та впровадження принципів гендерної рівності в усі сфери державної політики за рахунок вдосконалення та оцінки процедури прийняття рішень, удосконалення законодавчої бази та формування політичної стратегії у всіх сферах життя. Сучасні умови реформування поліції як центрального органу виконавчої влади поставили на порядок денний впровадження 
принципів гендерної політики в систему Національної поліції як вихідних положень проведення гендерної політики.

3 метою подальшого визначення принципів гендерної політики перш за все необхідно визначити категорію «принцип». У філософському енциклопедичному словнику поняття «принцип» визначається як першопочаток (від лат. ргіпсіріит - начало, основа), те, що лежить в основі певної сукупності фактів, теорії, науки. Античні філософи прагнули віднайти принципи існування усіх речей $\mathrm{i}$, зазвичай, пов'язували його із субстанцією. В XVI - XVII ст. в європейській філософії принцип почали тлумачити здебільшого як категорію теоретико-пізнавальну на основі розрізнення того, що лежить в основі дійсності, - принцип буття і того, що лежить в основі пізнання цієї дійсності, принцип пізнання. В подальшому розуміння принцип переміщується у сферу логічного виразу пізнання. Принцип стає центральним поняттям, основоположною ідеєю, що пронизує певну систему знання і субординує його. У межах теоретичного знання принцип означає вимогу розгортання самого знання у систему, де всі теоретичні положення логічно пов'язані між собою і випливають певним чином одне з одного. Будь яка теоретична система знання грунтується на принципах, пов'язаних між собою. Також «принцип» тлумачать як внутрішні переконання людини, ті практичні, моральні й теоретичні засади, якими вона керується в житті, в різноманітних сферах діяльності $[3$, c. 519$]$.

Державна гендерна політика повинна розглядатись як стратегія, що спрямована на забезпечення рівних прав, свобод та можливостей жінок і чоловіків, розвиток їх потенціалу у контексті розвитку гендерної демократії. Впровадження державної гендерної політики повинно здійснюватися шляхом спільних дій усіх зацікавлених суб'єктів. Гендерну політику в системі Національної поліції можна визначити як комплекс дій щодо забезпечення поліцейськими відповідного соціального статусу згідно з освітою, професійними і особистими якостями, рівнем культурного розвитку та потенціалом на основі гарантування рівних можливостей жінкам і чоловікам.

На підставі викладеного вище, можна зробити висновок, що сутність принципів гендерної політики в системі поліції, полягає в забезпеченні гендерної рівності та утвердження гендерної паритетності як фактору успішної реалізації демократичних реформ у державі. Зважаючи на це, можна виділити наступний перелік принципів гендерної політики в системі поліції:

- приниип інтеграції гендерної рівності - гендерна рівність розглядається як інтегральна частина всіх напрямів діяльності поліції. Під час упровадження різного роду програм, реалізації проектів мають 
бути враховані специфічні інтереси жінок і чоловіків. Жінкам i чоловікам мають бути надані рівні права;

- принциип наукової обгрунтованості передбачає формування та реалізацію гендерної політики в системі поліції на основі наукових досліджень, позитивного світового досвіду, залучення експертів 3 гендерних питань. Даний принцип вимагає володіння повною інформацією щодо умов забезпечення гендерної рівності в центральних та територіальних органах поліції, а також, передбачає здійснення моніторингу з метою з'ясування сучасного стану та динаміки гендерних процесів;

- принции законності - реалізація гендерної політики поліції має базуватися виключно на положеннях Конституції та чинного законодавства України й реалізуватися на основі Закону України "Про забезпечення рівних прав та можливостей жінок і чоловіків";

- принцип паритетної демократії - полягає у забезпеченні рівноцінної участі жінок і чоловіків як рівноправних суб'єктів у політичних, економічних, державотворчих, соціально-гуманітарних та культурних процесах. Даний принцип передбачає рівноцінне представництво жінок і чоловіків у будь-яких структурних підрозділах поліції і вимагає доступу представників обох статей до формування i реалізації гендерної політики;

- принции ініціативності та креативності - передбачає вияв ініціативи, креативного мислення, вміння творчо підходити до службових питань, а здатність до заохочування творчості інших;

- принцип оптимальності - полягає у вмінні керівництва обирати найкращого співробітника незалежно від статі, виходячи з професійних і особистісних якостей, досвіду, дисциплінованості, знання нормативної бази;

- принщип результативного партнерства - партнерство жінок і чоловіків у системі поліції, передбачає в першу чергу корисні наслідки співпраці, в основі якої лежить заінтересованість поліцейських у кінцевому результаті, що можливо лише, коли вони ставляться один до одного як до особистості і професіонала та сприймають один одного як компетентного і порядного партнера, дотримуються спільно розробленої системи правил дій на основі консенсусу i, головне, коли партнери доповнюють одне одного і здатні створити атмосферу співробітництва;

- принцип гуманізму - передбачає визнання гідності особистості та повагу до людини як визначальну цінність суспільства;

- принцип поєднання цінностей демократії із завданнями гендерної політики. Дія цього принципу має сприяти усвідомленню особистістю цінностей демократії (громадянство і громадянськість, свобода вибору і самовизначення, відповідальність, соціальний порядок, конституціоналізм, свобода слова і вільні засоби масової інформації, повага до 
громадської думки, розвиток особистості тощо) та забезпечувати їх включення в ії ціннісну ієрархію, що приведе до певного вибору моделі поведінки, а це, у свою чергу, буде сприяти адекватному сприйняттю особливостей i можливостей гендерної політики в системі поліції, визначенню завдань гендерної політики на всіх рівнях, розвитку відповідального ставлення до ії проведення, а відтак - впливатиме на якість гендерної політики.

\title{
Література:
}

1. Кобелянська Л. 50/50: сучасне гендерне мислення : словник / Л. Кобелянська, Т. Мельник. - К. : К.І.С., 2005. - 280 с.

2. Про забезпечення рівних прав та можливостей жінок і чоловіків: Закон України від 08.09.2005 р. № 2866-15 / Відомості Верховної Ради України, 2005, № 52, ст.561 .

3. Філософський енциклопедичний словник / В. І. Шинкарук (гол. редкол.) та ін. -: Інститут філософії ім. Григорія Сковороди НАН України : Абрис. Київ, 2002. - 742 с.

4. Грицяк Н. Формування гендерної політики в Україні: проблеми теорії, методології, практики : монографія / Наталя Грицяк. - К. : Вид-во НАДУ, 2004. - 384 с.

5. Кулачек О. Роль жінки в державному управлінні: старі образи, нові обрії : [монографія] / Ольга Кулачек. - К. : Вид-во Соломії Павличко “Основи”, 2005. - 304 с.

DOI https://doi.org/10.30525/978-9934-26-148-0-34

\section{ТЕОРЕТИКО-ПРИКЛАДНІ ПРОБЛЕМИ ВПРОВАДЖЕННЯ ПОДАТКОВОЇ АМНІСТІЇ В УКРАЇНІ}

\author{
Майка М. Б. \\ адвокат, кандидат юридичних наук, доцент кафедри права \\ Галищького коледжу імені В 'ячеслава Чорновола
}

\section{Глива А. О.}

студентка

Галицького коледжу імені В 'ячеслава Чорновола

м. Тернопіль, Україна

Вступ. Кризові явища як у світовій, так і в національній економіці, які загострилися через пандемію Covid-19, призвели до проблем залучення додаткових ресурсів в економіку кожної країни світу. 